\title{
Correction to: Treatment of Immature Scars: Manual Massages
}

Docteur N. Frasson, Marie Valange, Isabelle Almeras, Mathieu Izquierdo, and Gwenola Ster

\section{Correction to Chapter 25 in: L. Téot et al. (eds.), Textbook on Scar Management, https://doi.org/10.1007/978-3-030-44766-3_25}

Owing to an oversight on the part of the production, this chapter was initially published with incorrect authorship. The chapter was published with first author name alone, coauthors were inadvertently missed.

The authorship has now been updated with this erratum. 
Open Access This chapter is licensed under the terms of the Creative Commons Attribution 4.0 International License (http://creativecommons. org/licenses/by/4.0/), which permits use, sharing, adaptation, distribution and reproduction in any medium or format, as long as you give appropriate credit to the original author(s) and the source, provide a link to the Creative Commons license and indicate if changes were made.

The images or other third party material in this chapter are included in the chapter's Creative Commons license, unless indicated otherwise in a credit line to the material. If material is not included in the chapter's Creative Commons license and your intended use is not permitted by statutory regulation or exceeds the permitted use, you will need to obtain permission directly from the copyright holder. 